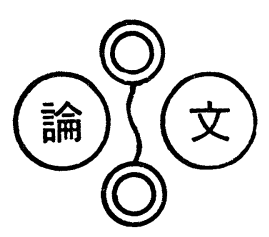

石炭還元メチル化物の構造解析 (III)

ーゲルパーミエーションクロマトグラフィーに

よる各種溶剤可溶分の分別—

-1983. 9. 8 受理一

富山大学 加藤 勉, 三宅 博之

厚主文弘，塚島寛

\section{1. 緒論}

石炭を適当な条件下 (常温, 常圧) でアニオン化し た後これにハロロゲン化アルキルを作用させたものは ベンゼンに良く溶解する。著者ら ${ }^{122}$ はこのいわゆる還 元アルキル化法による石炭の可溶化機構と石炭構造の 研究を目的として，これまでに夕張，太平洋両炭を還 元メチル化してこれらの各種溶剤への可溶化性と各可 溶分の平均構造などについて調べた。

本報では引き続き，両炭の各種溶剂可溶分をら゙ルパ ーミエーション クロマトグラフィー（G P C ) とよ り再分別した結果について報告する。

各種芳香族炭化水素のアニオン形成能 3 やアンオン 構造45)などに関する研究結果を早くにとりいれ，多環 の芳香族化合物よりなる石炭に応用した Sternberg $5^{6) \sim 8)}$ のこのニニークな石炭可溶化法も，報告以来既 に16年を経て関連報告も 30 報以上を数えるにいたって いる。報告内容は多岐にわたるが，その主たるものに， a）処理炭の可溶化性に関する Niemann $5^{9)}$, Alemany $5^{10)}$ の研究, b ) 可溶化性之可溶化物の構造特 性関するIgnasiakら ${ }^{11)}$ ，Dograら ${ }^{12)}$ ，Wachowska 13), Ouchi ら ${ }^{14)}$ の研究, この中にはアルカリ金属と直 接処理したLazarovら ${ }^{15)}$ の研究，テトラヒドロフラン (TH F)還流下に処理した Miyakeら ${ }^{16)}$ の研究などい くらか処理方法の異なるものも西る。またc）反応機 構に関するものにTsukashimaら ${ }^{17)}$ ，Franzら ${ }^{18)}$ (電 子移動剂), Larsen $5^{19)}$ (電子移動剂, $\mathrm{THF}$ ), Speight $5^{20)}$, Collins $5^{21)}$ (C-C 結合の切断), Eargle $\mathrm{Jr} .{ }^{22)}$, Itoh ら ${ }^{23)}$ (エーテル結合の切断), Ignasiakら 24) (Athabasca asphaltene, C-S結合の切断), 水素 化分解物と比較した Kuhlmann $5^{25)}$ ，反応を総括的 飞考察したAlemany ${ }^{26)}$ の研究，d）処理物のコーク ス化性や含酸素基含量の変化などについて調べたWa-

工学部工業化学科 富山県高岡市中川園町 $1-1$ chowskaら ${ }^{27)}$ の応用的研究がある。しかし可溶化成分 を各種の溶剤で逐次抽出し，これらをさらに分子量順 に細分別して構造特性を調べた研究はみうけられな い。処理生成物がぞのような性質の組成，成分よりな るのかを知っておくことは，石炭を可溶化寸るにも， またこれを利用する際にもきわめて重要なことと思克 る。

\section{2. 実験方法}

溶剤分別系統図をFig.1 飞示した。Fig.1 中のC S

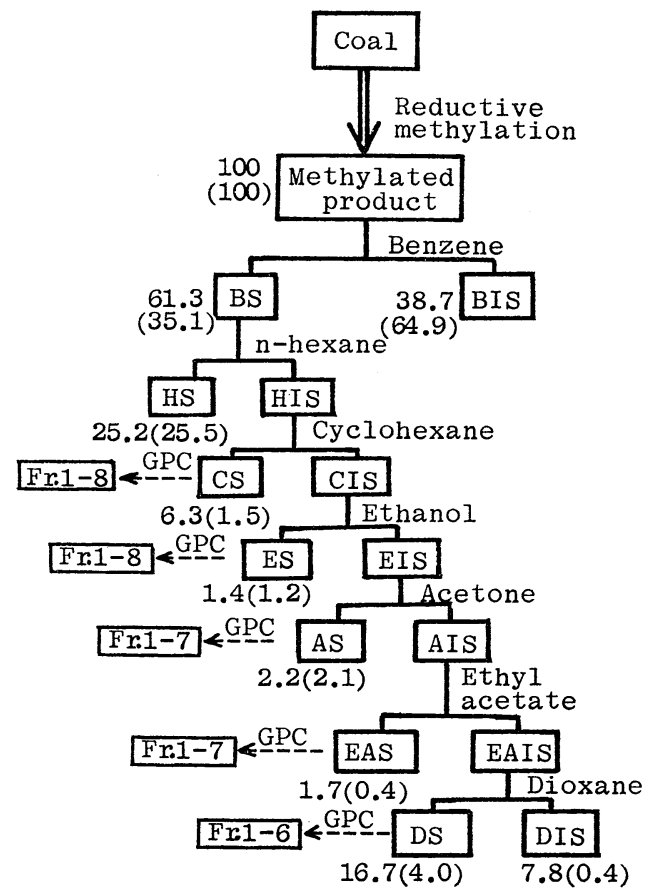

Values in parentheses are those for Taiheiyo coal

Fig. 1 Schematic diagram for solventfractionation of methylated Yubari and Taiheiyo coals 
Table 1 Preparative GPC-separation conditions of solvent-fractionation products

\begin{tabular}{|c|c|c|c|c|c|}
\hline Sample & Sample taken & Column & Packed gel & Flow rate & Cut vol. \\
\hline Yubari-CS & $2.10 \mathrm{~g} \times 2$ & \multirow{2}{*}{$\begin{array}{l}(25.4 \mathrm{~mm} \phi \times \\
1000 \mathrm{~mm}) \times 2\end{array}$} & \multirow{2}{*}{$\begin{array}{l}\text { 1. Bio beads, } \\
\text { S-X } 4 \\
\text { 2. Bio beads, } \\
\text { S-X1 }\end{array}$} & \multirow{2}{*}{$1 \mathrm{ml} / \mathrm{min}$. } & \multirow{2}{*}{$5.2 \mathrm{ml}$} \\
\hline Taiheiyo-CS & $0.80 \mathrm{~g} \times 2$ & & & & \\
\hline Yubari-ES & $0.55 \mathrm{~g}$ & \multirow{2}{*}{$\begin{array}{l}(25.4 \mathrm{~mm} \phi \times \\
1000 \mathrm{~mm}) \times 2\end{array}$} & \multirow{2}{*}{$\begin{array}{l}\text { 1. Bio beads, } \\
\text { S-X8 } \\
\text { 2. Bio beads, } \\
\text { S-X } 4\end{array}$} & \multirow{2}{*}{$1 \mathrm{ml} / \mathrm{min}$} & \multirow{2}{*}{$5.2 \mathrm{ml}$} \\
\hline Taiheiyo-ES & $1.55 \mathrm{~g}$ & & & & \\
\hline Yubari-AS & $1.74 \mathrm{~g}$ & $\begin{array}{l}(25.4 \mathrm{~mm} \phi \times \\
1000 \mathrm{~mm}) \times 2\end{array}$ & $\begin{array}{l}\text { 1. Bio beads, } \\
\text { S-X } 4 \\
\text { 2. Bio beads, } \\
\text { S-X1 }\end{array}$ & $1 \mathrm{ml} / \mathrm{min}$. & $5.2 \mathrm{ml}$ \\
\hline Taiheiyo-AS & $0.30 \mathrm{~g} \times 3$ & $\begin{array}{l}13.6 \mathrm{~mm} \phi \times \\
820 \mathrm{~mm}\end{array}$ & $\begin{array}{l}\text { Styragel } \\
\text { type } 200 \mathrm{~A}\end{array}$ & $0.3 \mathrm{~m} \ell / \mathrm{min}$. & $1.6 \mathrm{ml}$ \\
\hline Yubari-EAS & $0.26 \mathrm{~g} \times 4$ & $\begin{array}{l}13.6 \mathrm{~mm} \phi \times \\
820 \mathrm{~mm}\end{array}$ & $\begin{array}{l}\text { Styragel } \\
\text { type } 200 \mathrm{~A}\end{array}$ & $0.3 \mathrm{ml} / \mathrm{min}$. & $1.6 \mathrm{~m} \ell$ \\
\hline Taiheiyo-EAS & $0.37 \mathrm{~g}$ & $\begin{array}{l}(13.6 \mathrm{~mm} \phi \times \\
820 \mathrm{~mm}) \times 2\end{array}$ & $\begin{array}{l}\text { 1. Bio beads, } \\
\text { S-X } 4 \\
\text { 2. Styragel } \\
\text { type } 200 \mathrm{~A}\end{array}$ & $0.5 \mathrm{ml} / \mathrm{min}$ & $1.6 \mathrm{ml}$ \\
\hline Yubari-DS & $2.17 \mathrm{~g}$ & \multirow{2}{*}{$\begin{array}{l}(25.4 \mathrm{~mm} \phi \times \\
1000 \mathrm{~mm}) \times 2\end{array}$} & \multirow{2}{*}{$\begin{array}{l}\text { Bio beads, } \\
\text { S-X1 }\end{array}$} & \multirow{2}{*}{$1 \mathrm{~m} \ell / \mathrm{min}$} & \multirow{2}{*}{$5.2 \mathrm{m \ell}$} \\
\hline Taiheiyo-DS & $1.43 \mathrm{~g}$ & & & & \\
\hline
\end{tabular}

(シクロヘキサン可溶分), ES (エタノール可溶分), A S (アセトン可溶分), EAS (酢酸エチル可溶分), D S（ジオキサン可溶分）が本報の研究試料である。 な叔H S (n一ヘキサン可溶分)についてはすでに報告 2)した。

展開条件をまとめて Table 1 に示した。いずれも可 及的少量のベンゼンに溶解した試料をカラム上部から 入れベンゼンで展開した。溶出液はフラクションコレ クターで所定量を分取し, $50^{\circ} \mathrm{C}$, 減圧下に溶媒を留去 した後, シリカゲル上で $50^{\circ} \mathrm{C}, 48$ 時間以上真空乾燥し, 科量して溶出物の収量を求めた。

元素分析, IRならびに ${ }^{1} \mathrm{H}-\mathrm{NMR}$ スペクトルなどは 先報 ${ }^{2)}$ と同様に測定した。数平均分子量 (平均分子量 と以下略記する) はHitachi-Perkin-Elmer 115なら びに Corona 114を用い, 蒸気圧平衡法によりベンゼ ンを溶媒に, 槽内温度 $40^{\circ} \mathrm{C}$ で濃度を変えて 3 点以上測 定し $(0.2 \sim 1.0 \%)$ ，無限稀釈に括ける值を採用した。 なお检量線の作製には Benzil（MW，210，22）を用 い，装置は分解洗浄ごとに新たにこれを作製した。

\section{3. 結果および考察}

還元メチル化により各種の溶剤中に溶出してきた HS, CS, ES, AS, EAS, DSのベンゼン可溶分に占め
る割合は，夕張炭 $41.1 \%, 10.3 \%, 2.3 \%, 3.6 \%, 2.8$ $\%, 27.2 \%$ ，また太平洋炭は $72.6 \%, 4.3 \%, 3.4 \%$, $6.0 \% ， 1.1 \% ， 11.4 \%$ で，ことにHS と極性成分を多 く含むと推定される E S, A S は夕張炭よりも低品位 の太平洋炭に多く存在した1)。

5 種の溶剂可溶分の G P C 溶出曲線を Fig.2 に示し た。G P C 分別中に太平洋炭 E A S そとの $42.6 \%$ が Styragel（排除限界分子量, $M W_{E L} \approx 8000$ ）に吸着さ れて溶出せず，また真空デシケータに保存していたに もかかわらずD S $(\mathrm{MW}=47600)$ の約 $1 / 2$ がベンゼン に不溶となるなど，同種の溶剤可溶分ではあっても夕 張炭と太平洋炭とではかなり成分タイプは異なるよう に思われた。

各溶剂可溶分を平均分子量の大きなるのから順に 5 〜 8フラクション (Fr.) に分割し, Fr. no. と平均分 子量との関係を Fig. 3 に，また分子量範囲を Fig. 4 に 示した。Fig.3より各溶剤可溶分とも分子量の大きな ものから順によく分別されている。両炭 ES S分子量 は6 種の溶剤可溶分中HSに次いでともに低く，しか もこれらが無極性の n一ヘキサンとシクロヘキサンで 抽出した後にェタノール中に溶出してきた成分である ことから, E S 成分は, AS, EAS, DSないしDIS 中の 


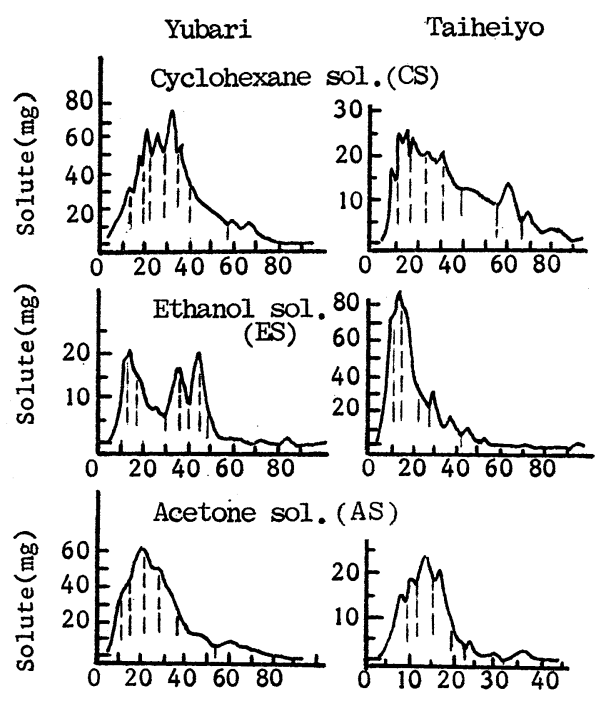

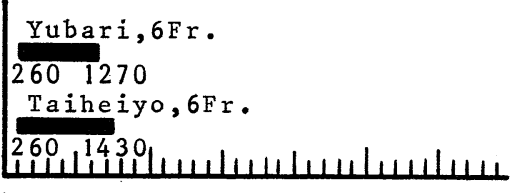

CS

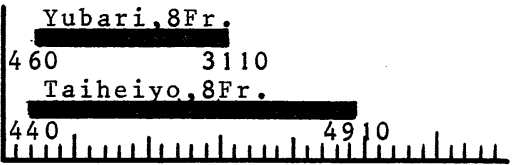

ES

Yubari, 8Fr.

$(310) *(2400) *$

Taiheiyo, $7 \mathrm{Fr}$.

429.

AS

$\frac{\text { Yubari, } 7 \mathrm{Fr}}{580}$

AS Taiheivo,7Fr.

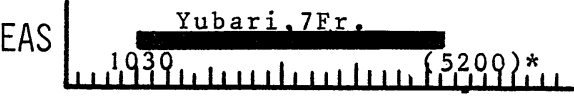

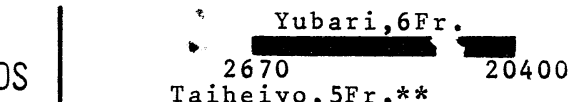

DS

Taiheiyo, $5 \mathrm{Fr} . * *$

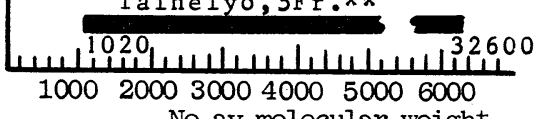

No.av.molecular weight

* Extrapolated values.

** $53 \%$ of DS having been soluble in benzene.

Fig. 4 Molecular weight distributions of solvent-fractionation products

$47600^{1)}$ であったことを併せて考光た場合に，本報の各 測定值が多少高めに出ていたとしても10万程度の分子 量成分がアスファルテン中に存在するであろらことは 十分推察される。な戚還元アルキル化物から10万程度 の大分子量成分が溶出寸るのか否かについては溶出を 示唆する結果がAlemany ${ }^{26)}$ PCollinsら ${ }^{211} の$ 報告に もみられる。

各溶剂可溶分の G P C 分別物について得られた知見 を以下 C Sょり順に記載する。

\section{1 シクロヘキサン可溶分 (C S)}

夕張, 太平洋両炭 $\mathrm{HS}$ の平均分子量はそれぞれ 430 と 390 なのに対し，C S の平均分子量はそれぞれ1180 と1130でともに $\mathrm{H}$ S の約 3 倍平均分子量は高かった1)。 両炭C S $8 \mathrm{Fr}$. に分割した。両炭のFr. 8 は黒色の夕 ール状であったが，他はいずれも黒色の固体であっ た。

G P C 分別物の収量, 平均分子量呿よび元素分析値 


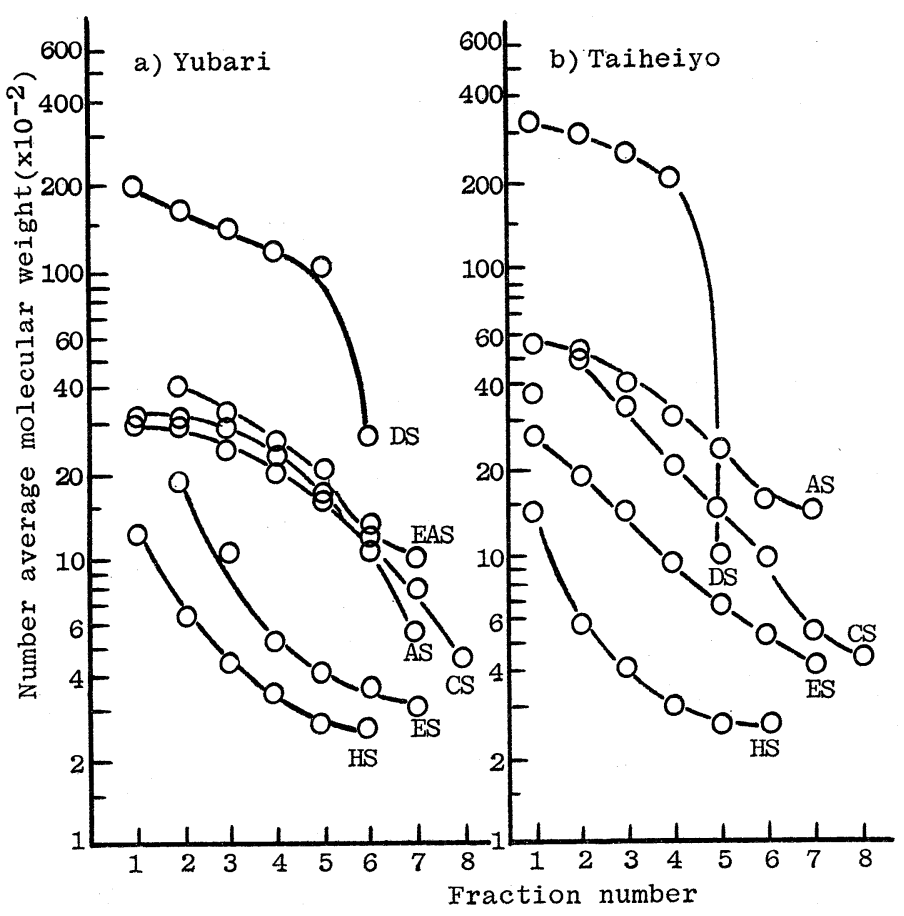

をまとめて Table 2に示した。夕張炭C $\mathrm{S}$ の平均分子量範囲は 3110 460 で, この中MW>3000の成分が約 $20 \% ， \mathrm{M}$ $\mathrm{W}<1000$ の成分が約 $29 \%$ を占めていた のに対し，太平洋炭C S の分子量範囲 は 4910〜440で，MW>3000の成分が 約 $35 \%, \mathrm{MW}<1000$ の成分が約 $34 \%$ と 夕張炭よりも太平洋炭の方に低分子量 成分も高分子量成分も多く含まれてい た。H SではMW>1000の留分が夕張 炭で13\%，太平洋炭で $9 \%$ であったの と比べても, シクロヘキサン中には非 常に分子量の高い成分が溶出したこと を示す。分子量測定の際, 夕張炭の GPC. Fr. 2, 3, 6 执よび太平洋炭のFr. 7 に濃度依存性があったが，他にはほ

Fig. 3 Fraction numbers versus number average molecular weights of GPC. fractions

Table 2 Yields ( $\%$, db), number average molecular weights (MW) and ultimate analyses ( $\%$, daf) of CS-GPC. fractions

a) Yubari-CS

\begin{tabular}{rrrrrrrr}
\hline $\begin{array}{l}\text { Fr. } \\
\text { no. }\end{array}$ & Yield & MW & $\mathrm{C}$ & $\mathrm{H}$ & $\mathrm{O}$ & \multicolumn{3}{c}{ Atomic ratio } \\
\hline 1 & & & & & $\mathrm{H} / \mathrm{C}$ & $\mathrm{O} / \mathrm{C}$ \\
2 & 10.6 & 3110 & 81.6 & 7.6 & 10.8 & 1.11 & 0.099 \\
3 & 11.4 & 3090 & 83.5 & 7.4 & 9.1 & 1.05 & 0.082 \\
4 & 14.2 & 2440 & 83.6 & 7.4 & 9.0 & 1.05 & 0.081 \\
5 & 13.9 & 1690 & 82.2 & 7.1 & 10.7 & 1.04 & 0.086 \\
6 & 10.9 & 1330 & 82.1 & 7.1 & 10.8 & 1.03 & 0.098 \\
7 & 18.5 & 790 & 83.2 & 8.3 & 8.5 & 1.19 & 0.099 \\
8 & 10.6 & 460 & 79.5 & 8.6 & 11.9 & 1.29 & 0.077 \\
\hline
\end{tabular}

b) Taiheiyo-CS

\begin{tabular}{crrrrrrr}
\hline $\begin{array}{l}\text { Fr. } \\
\text { no. }\end{array}$ & Yield & MW & $\mathrm{C}$ & $\mathrm{H}$ & $\mathrm{O}^{*}$ & \multicolumn{2}{c}{ Atomic ratio } \\
\hline 1 & 6.5 & 3640 & 80.7 & 9.1 & 10.2 & 1.34 & $\mathrm{H} / \mathrm{C}$ \\
2 & 13.1 & 4910 & 79.9 & 8.6 & 11.5 & 1.28 & 0.095 \\
3 & 15.2 & 3260 & 79.2 & 8.0 & 12.8 & 1.20 & 0.121 \\
4 & 18.1 & 2060 & 78.6 & 7.5 & 13.9 & 1.14 & 0.133 \\
5 & 9.7 & 1480 & 78.3 & 7.2 & 14.5 & 1.09 & 0.139 \\
6 & 14.5 & 970 & 79.0 & 7.7 & 13.3 & 1.16 & 0.126 \\
7 & 11.4 & 540 & 78.0 & 8.0 & 14.0 & 1.22 & 0.135 \\
8 & 8.4 & 440 & 78.5 & 7.7 & 13.8 & 1.17 & 0.132 \\
\hline
\end{tabular}

* By difference 
a) Yubari-CS

Table 3 Structural parameters of CS-GPC. fractions

\begin{tabular}{cccccccc}
\hline $\begin{array}{c}\text { Fr. } \\
\text { no. }\end{array}$ & $\mathrm{fa}$ & $\sigma \mathrm{al}$ & $\sigma \mathrm{c}$ & $\mathrm{Hau} / \mathrm{Ca}$ & $\mathrm{Ho} / \mathrm{H} \alpha$ & $\mathrm{M}(\mathrm{Us})$ & $\mathrm{n}$ \\
\hline 1 & 0.53 & 0.40 & 0.23 & 0.83 & 1.7 & 254 & 12.2 \\
2 & 0.56 & 0.39 & 0.19 & 0.78 & 1.5 & 273 & 11.3 \\
3 & 0.58 & 0.39 & 0.18 & 0.81 & 1.3 & 241 & 10.1 \\
4 & 0.57 & 0.44 & 0.18 & 0.82 & 1.2 & 240 & 8.5 \\
5 & 0.58 & 0.41 & 0.20 & 0.83 & 1.1 & 228 & 7.4 \\
6 & 0.59 & 0.38 & 0.21 & 0.83 & 1.2 & 227 & 5.9 \\
7 & 0.52 & 0.38 & 0.16 & 0.93 & 1.7 & 195 & 4.1 \\
8 & 0.46 & 0.30 & 0.25 & 0.99 & 3.0 & 202 & 2.3 \\
\hline
\end{tabular}

b) Taiheiyo-CS

\begin{tabular}{cccccccc}
\hline $\begin{array}{c}\text { Fr. } \\
\text { no. }\end{array}$ & fa & $\sigma$ al & $\sigma o$ & Hau/Ca & Ho/H $\alpha$ & M(Us) & $\mathrm{n}$ \\
\hline 1 & 0.40 & 0.44 & 0.22 & 1.06 & 2.2 & 198 & 18.4 \\
2 & 0.42 & 0.46 & 0.26 & 1.01 & 2.0 & 210 & 23.4 \\
3 & 0.46 & 0.46 & 0.27 & 0.97 & 1.6 & 209 & 15.6 \\
4 & 0.51 & 0.44 & 0.26 & 1.00 & 1.2 & 180 & 11.4 \\
5 & 0.53 & 0.43 & 0.26 & 0.99 & 1.1 & 176 & 8.4 \\
6 & 0.50 & 0.41 & 0.26 & 0.98 & 1.5 & 188 & 5.2 \\
7 & 0.47 & 0.34 & 0.30 & 0.96 & 2.4 & 211 & 2.6 \\
8 & 0.53 & 0.32 & 0.25 & 1.01 & 1.7 & 168 & 2.6 \\
\hline
\end{tabular}

$\mathrm{Ha} ; \delta=9.0-6.0 \mathrm{ppm}, \mathrm{H} \alpha ; \delta=4.6-2.0 \mathrm{ppm}, \mathrm{Ho} ; \delta=2.0-0.1 \mathrm{ppm}$

fa; Carbon aromaticity

$\sigma$; The degree of the substitution of the aromatic system

$\sigma a l$; Aliphatic substitution

$\sigma o$; Substitution by oxygen containing groups

$\mathrm{Hau} / \mathrm{Ca}$; The aromatic hydrogen to carbon ratio of the hypothetical unsubstituted aromatic material

$\mathrm{Ho} / \mathrm{H} \alpha$; Average length of aliphatic carbon chains

$\mathrm{M}(\mathrm{Us})$; Structural unit weight

$\mathrm{n}=\mathrm{MW} / \mathrm{M}(\mathrm{Us})$

とんど認められなかった。GPC.Fr. 中，濃度依存性 が認められた Fr. と認められなかったFr.のIRスペク トルと各構造パラメータを比較して両 Fr. 間にはとく に差異はみられなかった。また還元メチル化によって 石炭中のフェノール性 $\mathrm{OH}$ のほとんどが $\mathrm{CH}_{3} \mathrm{O}$ 基に変 化していると考えられることから ${ }^{6)}$ ，溶質分子会合の 原因は水素結合以外の分子間力によるのではないかと 思われた。

GPC.Fr.の各構造バラメータとその推移をTable 3 とFig.5にそれぞれ示した。な拉Fig.5には比較のた めHSの結果を併記した。H Sと比較して両炭C Sの 各構造 パラメータの 分布範囲は狭く, ことに夕張炭 Fr. 2〜6 (収率61\%) の $\mathrm{fa}, \sigma \mathrm{al}, \sigma \mathrm{o}, \mathrm{Hau} / \mathrm{Ca}$ の分布範
囲は, 平均值士0.03でこれらはきわめて単位構造の類 似した成分からなると推定された。他方構造単位質量 $\mathrm{M}\left(\mathrm{Us}_{\mathrm{s}}\right)$ と重合度 $\mathrm{n}$ との関係からは, 夕張, 太平洋両

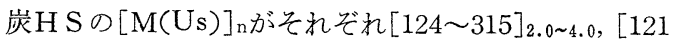
〜208]2.1 7.6なのに対し, C S ではそれぞれ[195〜273] 2.3 12.2, [168 211 $]_{2.6 \sim 23.4}$ と, 両炭C S ともH S に比 ベてnの範囲が広く, また炭種間では夕張炭よりも太 平洋炭の方が $\mathrm{M}(\mathrm{Us})$ は若干小さく， $\mathrm{n}$ は大きかった。

\section{2 エ夕ノール可溶分 (E S )}

前述のように, この可溶分は夕張炭よりも低品位の 太平洋炭に比較的多く, アセトン可溶分と同じく極性 成分を多く含むと推定される留分である。酸素含量は 6 種の溶剤可溶分中で最も高かった ${ }^{1} 。$ 


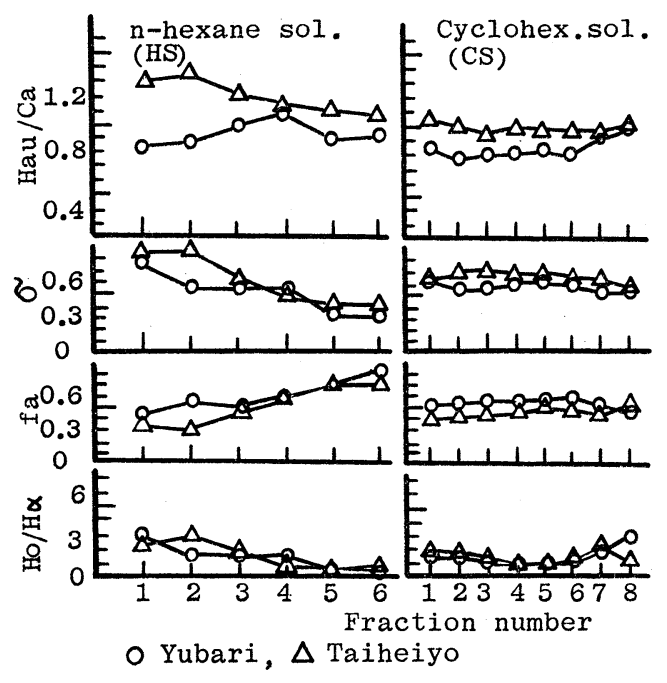

Fig. 5 Structural parameters versus fraction no. of GPC. fractions
夕張炭の G P C 溶出曲線は 3 つの極大值を有し他と はやや異なる形状を示した(Fig.2)。両炭ESを7〜8 Fr.に分割した。夕張炭 GPC.Fr.4〜7 は褐色ないし 櫈色の，またFr.8は黒色のそれぞれタール状物質で あったが，他は太平洋炭も含めていずれも黑色の固体 であった。

GPC 分別物の収率, 平均分子量ならびに元素分析 值をまとめて Table 4 に示した。両炭E Sでは, MW <600 の留分が太平洋炭約 16\%なのに対し, 夕張炭で は約 $58 \%$ でその多くが低分子量の成分で占められてい た。な执平洋炭のGPC.Fr.1拈よび Fr. 4〜7には平 均分子量測定時に濃度依存性がなかった。

構造パラメータを Table 5 に示した。石炭中のアリ ルアルキルエーテル (Ar.OR) より生成した高沸点の 長鎖アルキルェーテル $\left(\mathrm{ROCH}_{3}\right)$ はn一ヘキサンならび にシクロヘキサン中にとどまり，低沸点エーテルは溶 媒留去中に逸散したと思われるが，ジアリルエーテル ならびにフェノール類より生成した $\mathrm{Ar} . \mathrm{OCH}_{3}$ ，执よ びジサルファイド類から生じた Ar. $\mathrm{SCH} 3$ などがこの

Table 4 Yields $(\%, \mathrm{db})$, number average molecular weights (MW) and ultimate analyses ( $\%$, daf) of ES-GPC. fractions

a) Yubari-ES

\begin{tabular}{|c|c|c|c|c|c|c|c|}
\hline \multirow{2}{*}{$\begin{array}{l}\text { Fr. } \\
\text { no. }\end{array}$} & \multirow[b]{2}{*}{ Yield } & \multirow[b]{2}{*}{ MW } & \multirow[b]{2}{*}{$\mathrm{C}$} & \multirow{2}{*}{$\mathrm{H}$} & \multirow{2}{*}{$\mathrm{O}^{*}$} & \multicolumn{2}{|c|}{ Atomic ratio } \\
\hline & & & & & & $\mathrm{H} / \mathrm{C}$ & $\mathrm{O} / \mathrm{C}$ \\
\hline 1 & 7.2 & $(2400)$ & 74.3 & 7.4 & 18.3 & 1.19 & 0.185 \\
\hline 2 & 13.3 & 1800 & 73.6 & 6.9 & 19.5 & 1.11 & 0.200 \\
\hline 3 & 20.3 & 1090 & 71.9 & 6.7 & 21.4 & 1.11 & 0.224 \\
\hline 4 & 9.9 & 530 & 74.2 & 8.1 & 17.7 & 1.30 & 0.179 \\
\hline 5 & 10.1 & 410 & 74.1 & 8.8 & 17.1 & 1.42 & 0.173 \\
\hline 6 & 9.5 & 370 & 72.0 & 8.0 & 20.0 & 1.32 & 0.209 \\
\hline 7 & 13.4 & 310 & 69.8 & 7.5 & 22.7 & 1.27 & 0.245 \\
\hline 8 & 14.9 & - & 75.9 & 7.8 & 16.3 & 1.22 & 0.161 \\
\hline
\end{tabular}

b) Taiheiyo-ES

\begin{tabular}{cccccccc}
\hline $\begin{array}{l}\text { Fr. } \\
\text { no. }\end{array}$ & Yield & MW & $\mathrm{C}$ & $\mathrm{H}$ & $\mathrm{O} *$ & \multicolumn{2}{c}{ Atomic ratio } \\
\hline 1 & 18.3 & 2580 & 76.5 & 6.9 & 16.6 & $\mathrm{H} / \mathrm{C}$ & $\mathrm{O} / \mathrm{C}$ \\
2 & 16.4 & 1920 & 73.7 & 6.7 & 1.08 & 0.163 \\
3 & 31.0 & 1450 & 72.2 & 6.5 & 21.3 & 1.09 & 0.200 \\
4 & 10.1 & 950 & 77.4 & 6.3 & 16.3 & 0.97 & 0.221 \\
5 & 5.9 & 670 & 77.2 & 7.3 & 15.5 & 1.12 & 0.158 \\
6 & 6.9 & 530 & 76.6 & 6.7 & 16.7 & 1.05 & 0.163 \\
7 & 9.0 & 420 & 76.3 & 6.9 & 16.8 & 1.08 & 0.165 \\
\hline
\end{tabular}

* By difference 
Table 5 Structural parameters of ES-GPC. fractions

a) Yubari-ES

\begin{tabular}{|c|c|c|c|c|c|c|c|}
\hline \multirow{2}{*}{$\begin{array}{l}\text { Fr. } \\
\text { no. }\end{array}$} & \multirow[b]{2}{*}{$\mathrm{fa}$} & \multicolumn{4}{|c|}{ Structural parameter } & \multirow[b]{2}{*}{$\mathrm{M}\left(\mathrm{Us}_{\mathrm{s}}\right)$} & \multirow[b]{2}{*}{$\mathrm{n}$} \\
\hline & & $\sigma$ al & $\sigma 0$ & $\mathrm{Hau} / \mathrm{Ca}$ & $\mathrm{Ho} / \mathrm{H} \alpha$ & & \\
\hline 1 & 0.50 & 0.31 & 0.34 & 1.11 & 1.8 & 158 & - \\
\hline 2 & 0.55 & 0.32 & 0.33 & 1.09 & 1.4 & 150 & 12.0 \\
\hline 3 & 0.55 & 0.31 & 0.35 & 1.15 & 1.3 & 141 & 7.7 \\
\hline 4 & 0.46 & 0.27 & 0.33 & 1.17 & 2.7 & 157 & 3.4 \\
\hline 5 & 0.39 & 0.27 & 0.33 & 1.31 & 3.4 & 152 & 2.7 \\
\hline 6 & 0.46 & 0.25 & 0.36 & 1.28 & 2.7 & 140 & 2.7 \\
\hline 7 & 0.49 & 0.23 & 0.38 & 1.30 & 2.6 & 133 & 2.3 \\
\hline 8 & 0.51 & 0.28 & 0.29 & 1.11 & 2.0 & 151 & - \\
\hline \multicolumn{8}{|c|}{ b) Taiheiyo-ES } \\
\hline \multicolumn{3}{|l|}{$\mathrm{Fr}$} & \multicolumn{3}{|c|}{ Structural parameter } & & \\
\hline no. & $\mathrm{fa}$ & $\sigma \mathrm{al}$ & $\sigma \mathrm{o}$ & $\mathrm{Hau} / \mathrm{Ca}$ & $\mathrm{Ho} / \mathrm{H} \alpha$ & $\mathrm{M}\left(\mathrm{U}_{\mathrm{s}}\right)$ & $\mathrm{n}$ \\
\hline 1 & 0.55 & 0.38 & 0.30 & 1.00 & 1.1 & 171 & 15.1 \\
\hline 2 & 0.55 & 0.37 & 0.33 & 1.10 & 1.1 & 150 & 12.8 \\
\hline 3 & 0.56 & 0.36 & 0.33 & 1.17 & 0.9 & 132 & 10.9 \\
\hline 4 & 0.62 & 0.37 & 0.28 & 0.94 & 0.8 & 171 & 5.6 \\
\hline 5 & 0.54 & 0.36 & 0.28 & 1.01 & 1.4 & 170 & 4.0 \\
\hline 6 & 0.57 & 0.33 & 0.31 & 0.92 & 1.5 & 196 & 2.7 \\
\hline 7 & 0.58 & 0.27 & 0.30 & 0.96 & 1.8 & 177 & 2.3 \\
\hline
\end{tabular}

Table 6 Yields (\%, db), number average molecular weights (MW) and ultimate analyses ( $\%$, daf) of AS-GPC. fractions

a) Yubari-AS

\begin{tabular}{|c|c|c|c|c|c|c|c|}
\hline \multirow{2}{*}{$\begin{array}{l}\text { Fr. } \\
\text { no. }\end{array}$} & \multirow{2}{*}{ Yield } & \multirow{2}{*}{ MW } & \multirow{2}{*}{$\mathrm{C}$} & \multirow{2}{*}{$\mathrm{H}$} & \multirow{2}{*}{$\mathrm{O}^{*}$} & \multicolumn{2}{|c|}{ Atomic ratio } \\
\hline & & & & & & $\mathrm{H} / \mathrm{C}$ & $\mathrm{O} / \mathrm{C}$ \\
\hline 1 & 6.0 & 3120 & 79.5 & 6.5 & 14.0 & 0.98 & 0.133 \\
\hline 2 & 6.4 & 3070 & 80.3 & 6.4 & 13.3 & 0.94 & 0.125 \\
\hline 3 & 17.5 & 2860 & 80.8 & 6.4 & 12.8 & 0.94 & 0.119 \\
\hline 4 & 22.0 & 2270 & 81.1 & 6.4 & 12.5 & 0.94 & 0.116 \\
\hline 5 & 18.4 & 1670 & 82.0 & 6.3 & 11.7 & 0.92 & 0.107 \\
\hline 6 & 17.1 & 1170 & 82.0 & 6.3 & 11.7 & 0.92 & 0.108 \\
\hline 7 & 8.7 & 580 & 79.8 & 6.6 & 13.6 & 0.98 & 0.129 \\
\hline \multicolumn{8}{|c|}{ b) Taiheiyo-AS } \\
\hline \multirow{2}{*}{$\begin{array}{l}\text { Fr. } \\
\text { no. }\end{array}$} & \multirow{2}{*}{ Yield } & \multirow{2}{*}{ MW } & \multirow{2}{*}{$\mathrm{C}$} & \multirow{2}{*}{$\mathrm{H}$} & \multirow{2}{*}{$\mathrm{O}^{*}$} & \multicolumn{2}{|c|}{ Atomic ratio } \\
\hline & & & & & & $\mathrm{H} / \mathrm{C}$ & $\mathrm{O} / \mathrm{C}$ \\
\hline 1 & 8.5 & 5580 & 77.0 & 6.8 & 16.2 & 1.06 & 0.158 \\
\hline 2 & 21.7 & 5350 & 77.4 & 6.8 & 15.8 & 1.05 & 0.153 \\
\hline 3 & 23.7 & 4010 & 77.7 & 6.7 & 15.6 & 1.02 & 0.152 \\
\hline 4 & 19.5 & 3100 & 77.6 & 6.6 & 15.8 & 1.01 & 0.153 \\
\hline 5 & 12.6 & 2350 & 77.3 & 6.5 & 16.2 & 1.01 & 0.158 \\
\hline 6 & 6.1 & 1570 & 77.9 & 6.6 & 15.5 & 1.00 & 0.149 \\
\hline 7 & 5.2 & 1410 & 76.7 & 6.8 & 16.5 & 1.05 & 0.162 \\
\hline
\end{tabular}

* By difference 
エタノールと次のアセトンの両可溶分中に多く存在す ると推定される。夕張炭 $\mathrm{E} \mathrm{S}$ は 6 種の溶剤可溶分中で 最も $\mathrm{fa}, \sigma \mathrm{al}, \mathrm{M}\left(\mathrm{Us}_{\mathrm{s}}\right)$ が低く，かつ $\sigma \mathrm{o}$ の大きな成分よ りなり，乙かも夕張宸 $\mathrm{fa}$ が太平洋炭 $\mathrm{fa}$ より低いのも このESのみであった（Fig.6)。

\section{3 アセトン可溶分 (AS)}

両炭ASをともに7Fr.に分割した。各G PC分別 物の収率，平均分子量ならびに元素分析值を Table 6 に示した。両炭 $\mathrm{AS}$ S O/Cは 6 種の溶剤可溶分中 $\mathrm{ES}$ に次いで大きく，しかも E S では夕張炭の方が大きか ったが，A S では逆に太平洋炭の方が大きかった。炭 種間に打ける差異は炭素含量（夕張炭 $80.8 \pm 1.3 \%$, 太平洋炭 $77.3 \pm 0.6 \%$ ）のならず 分子量分布にも認 められ, 夕張炭 $(\mathrm{MW}=3100 \sim 580)$ よりも太平洋炭 （MW=5600 1400）に高分子量成分が多くしかも分 子量1400以下の成分がきわめて少なかった。な打平均 分子量測定の際, 両炭 ES 以降のいずれの溶剂可溶分 (AS, EAS, DS) の G P C 分別物にも濃度依存性は認 められた。

G P C 分別物の構造パラメータを Table 7にまた その推移をESの結果と併せて Fig. 6 亿示した。Fig. 6 より, 夕張炭A S は太平洋炭A Sよりも芳香族性が 高く, 脂肪族置換, 含酸素基置換とも一様に低いが, 両
炭の各構造パラィータはそれぞれ横ばい状態で E S と 比較してその変化は小さい。颃々らく分子量の比較的 小さい成分やタイプの異なった成分の多くが $\mathrm{ES}$ 中に すでに溶出してしまったためと思われる。Table 7 か

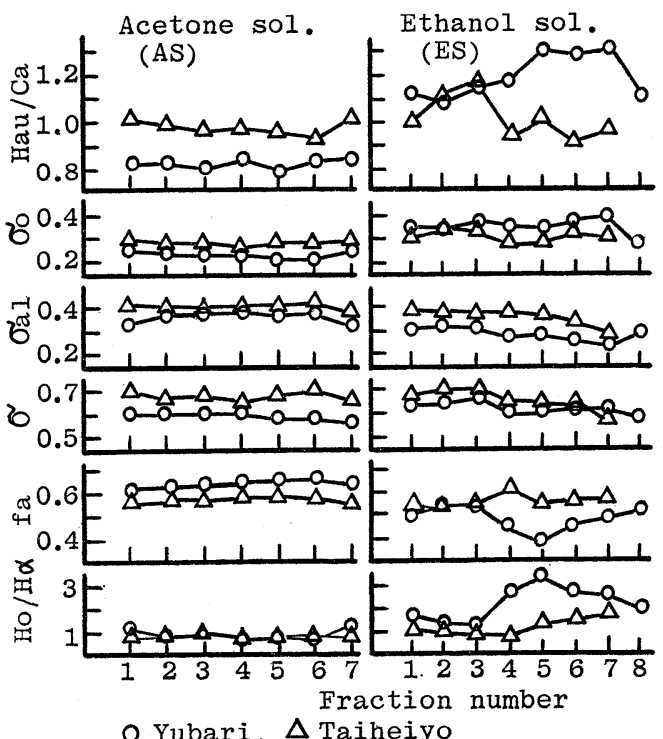

Fig. 6 Structural parameters versus fraction no. of GPC. fractions

Table 7 Structural parameters of AS-GPC. fractions

a ) Yubari-AS

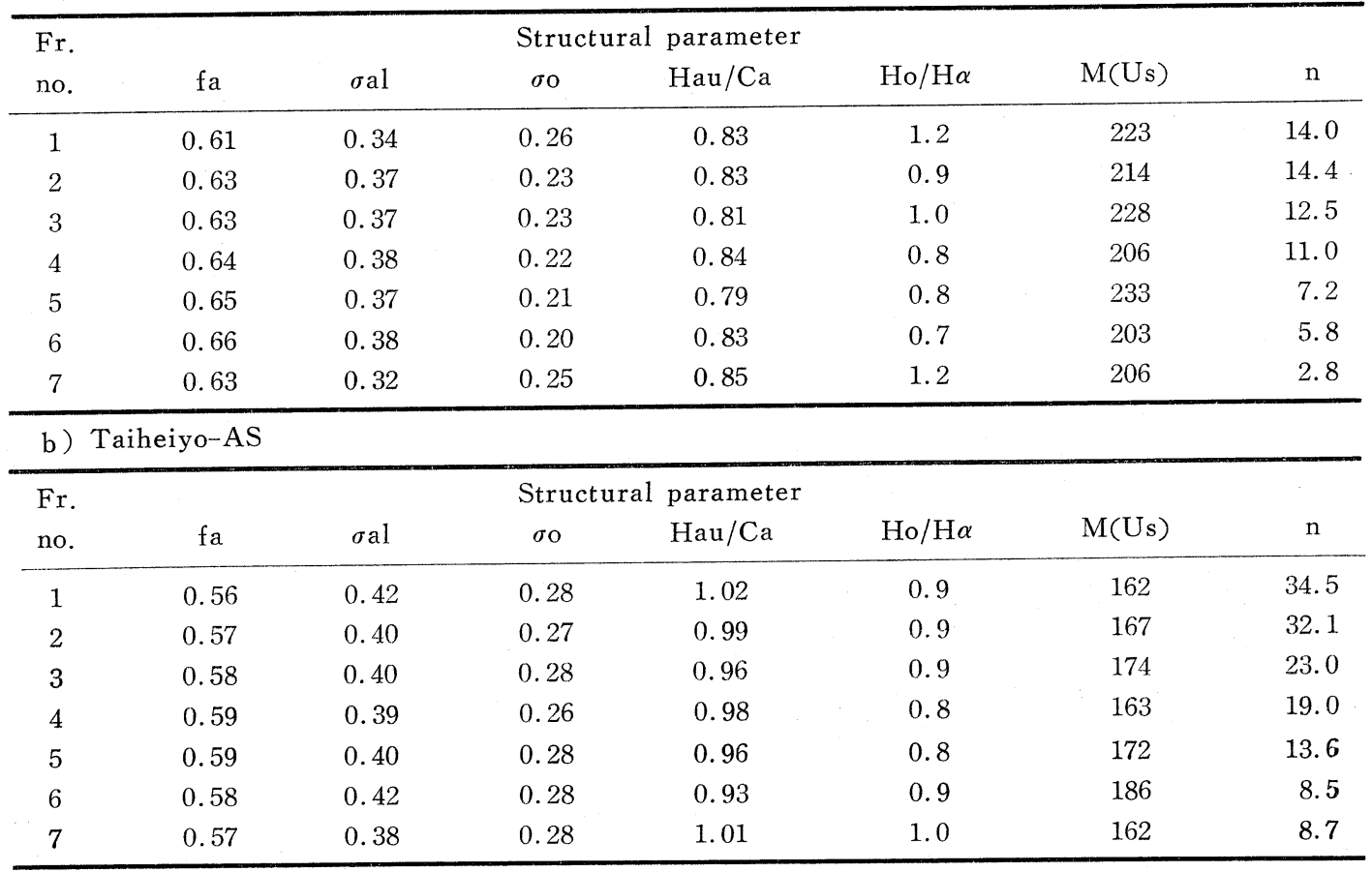


ら, 両炭A S の単位構造に, 夕張炭 $[200 \sim 230]_{3 \sim 14}$, 太 平洋炭 $[160 \sim 190]_{9 \sim 35}$ のような差異がみられる。

3.4 酢酸エチル可溶分 (E A S)

夕張, 太平洋両炭ベンゼン可溶分中それぞれ $2.8 \%$
（MW=2910）と1.1\%（MW=1120）を占めた留分で

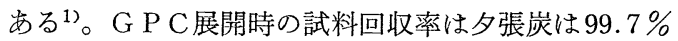
であったが，太平洋炭は $57.4 \%$ とその 4 割程度が充媜 剂に吸着され，試料不足から分子量その他が測定でき

Table 8 Yields ( $\%$, db), number average molecular weights (MW) and ultimate analyses ( $\%$, daf) of EAS-GPC. fractions

a) Yubari-EAS

\begin{tabular}{|c|c|c|c|c|c|c|c|}
\hline \multirow{2}{*}{$\begin{array}{l}\text { Fr. } \\
\text { no. }\end{array}$} & \multirow{2}{*}{ Yield } & \multirow{2}{*}{ MW } & \multirow{2}{*}{$\mathrm{C}$} & \multirow{2}{*}{$\mathrm{H}$} & \multirow{2}{*}{$\mathrm{O}^{*}$} & \multicolumn{2}{|c|}{ Atomic ratio } \\
\hline & & & & & & $\mathrm{H} / \mathrm{C}$ & $\mathrm{O} / \mathrm{C}$ \\
\hline 1 & 4.2 & - & 82.2 & 6.3 & 11.5 & 0.91 & 0.104 \\
\hline 2 & 14.3 & 4020 & 83.6 & 6.7 & 9.7 & 0.95 & 0.087 \\
\hline 3 & 21.1 & 3260 & 84.0 & 6.7 & 9.3 & 0.94 & 0.083 \\
\hline 4 & 21.1 & 2600 & 84.3 & 6.7 & 9.0 & 0.95 & 0.080 \\
\hline 5 & 17.4 & 2080 & 84.0 & 6.4 & 9.6 & 0.91 & 0.086 \\
\hline 6 & 8.9 & 1120 & 83.4 & 6.9 & 9.7 & 0.98 & 0.087 \\
\hline 7 & 12.7 & 1030 & 80.8 & 6.9 & 12.3 & 1.02 & 0.114 \\
\hline \multicolumn{8}{|c|}{ b) Taiheiyo-EAS } \\
\hline \multirow{2}{*}{$\begin{array}{l}\text { Fr. } \\
\text { no. }\end{array}$} & \multirow{2}{*}{ Yield } & \multirow{2}{*}{$\mathrm{MW}$} & \multirow{2}{*}{$\mathrm{C}$} & \multirow{2}{*}{$\mathrm{H}$} & \multirow{2}{*}{$\mathrm{O}^{*}$} & \multicolumn{2}{|c|}{ Atomic ratio } \\
\hline & & & & & & $\mathrm{H} / \mathrm{C}$ & $\mathrm{O} / \mathrm{C}$ \\
\hline 1 & 2.3 & - & - & - & - & - & - \\
\hline 2 & 10.9 & - & 78.5 & 6.7 & 14.8 & 1.02 & 0.142 \\
\hline 3 & 14.1 & - & 78.6 & 6.8 & 14.6 & 1.03 & 0.139 \\
\hline 4 & 11.9 & - & 78.8 & 6.8 & 14.4 & 1.03 & 0.137 \\
\hline
\end{tabular}

Yield of fraction, Fr. $5 ; 6.3 \%$, Fr. $6 ; 4.1 \%$, Fr. $7 ; 7.8 \%$

* By difference

Table 9 Structural parameters of EAS-GPC. fractions

a) Yubari-EAS

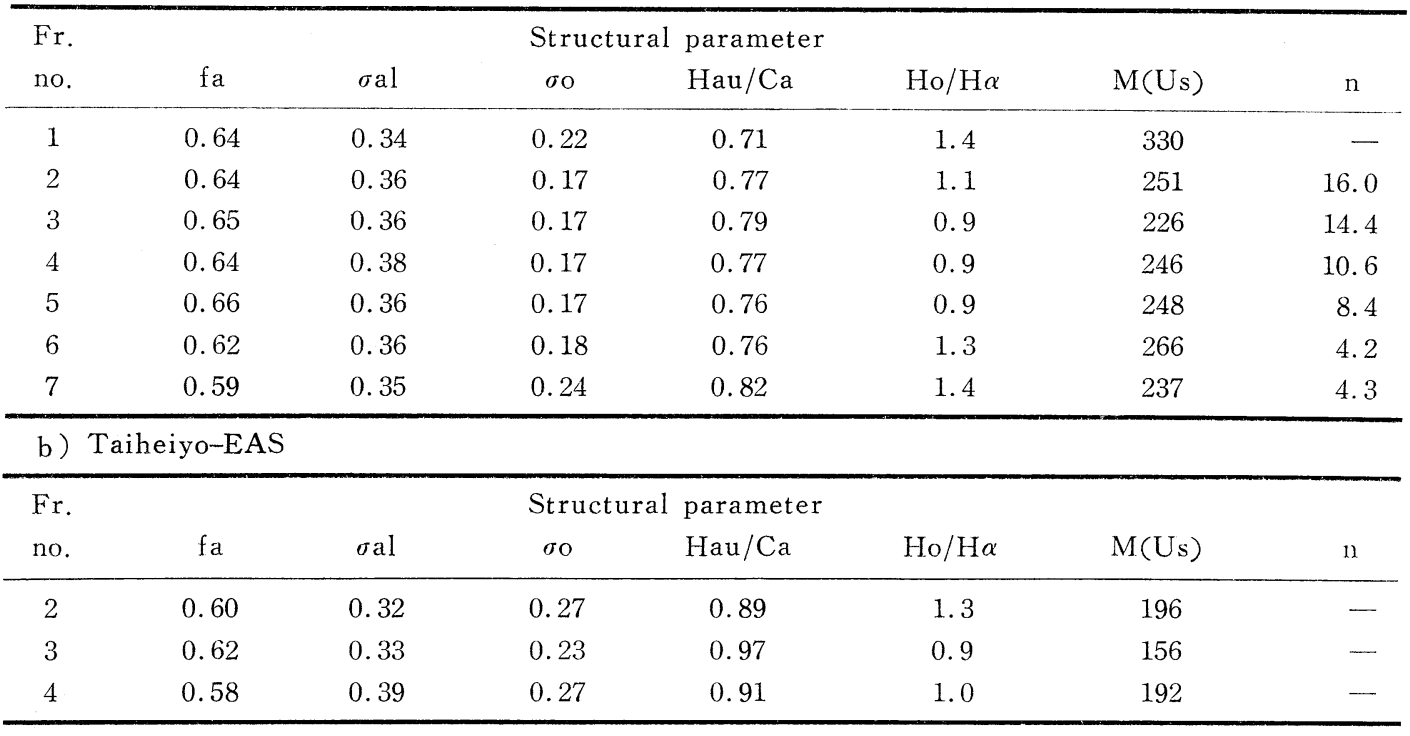


なくなった。

両炭EASをそれぞれ7Fr.に分割し，測定しえた各 G P C 分別物の収率, 平均分子量ならびに元素分析値 を Table 8 に，構造パラメータとその推移を Table 9 とFig.7 にそれぞれ示した。石炭成分の溶剤による分 別効果が逐次抽出のあとになるほど明瞭になるためか GPC.Fr.の元素分析值ならびに構造パラメータの分 布範囲が概して次第に狭まってくる傾向がみられる。 夕張炭 GPC. Fr.1 7に拉けるC\%のR'（=最大值一 最小值）は3.5\%，H\%の R'は0.6\%であるが，Fr.1 と Fr. 7 を除くFr. 2〜6の $\mathrm{R}^{\prime} \mathrm{C} \%$ は $0.9 \%, \mathrm{R}_{\mathrm{H}}^{\prime} \%$ は 0.5 \%となり，かつこれらの構造パラメータも比較的類似 していた（fa, $\sigma \mathrm{al}, \sigma \mathrm{o}, \mathrm{Hau} / \mathrm{Ca} の$ 各 $\mathrm{R}^{\prime}$ は0.04以内に ある)。

\section{5 ジオキサン可溶分 (D S )}

夕張炭D S $27.2 \%(\mathrm{MW}=6070)$, また太平洋炭D $\mathrm{S}$ は $11.4 \%(\mathrm{MW}=47600)$ を占め, ともにベンゼン可溶 分中 $\mathrm{n}$-ヘキサン 可溶分に次いで多量に存在する留分 である1。前述のよらに高分子量成分を含む太平洋炭 D S は保存中に $46.6 \%$ がベンゼンに不溶化し，そのす べてを展開できなかった。Sternbergら $n$ tas (lvb) Coal (88.3\% C) 還元エチル化物（B S 収
Ethyl acetate sol.
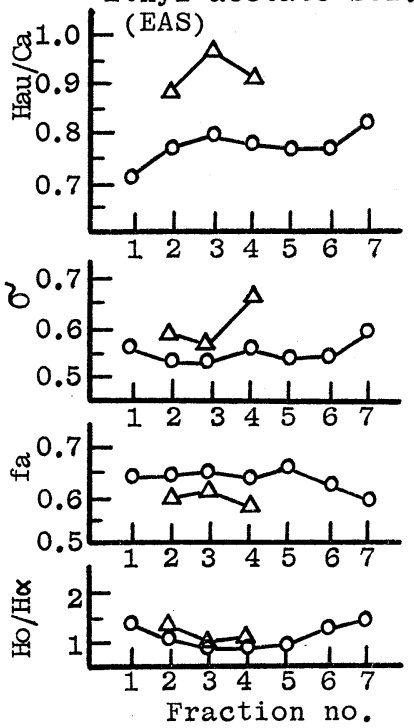

o Yubari, $\Delta$ Taiheiyo

Fig. 7 Structural parameters versus fraction no. of GPC. fractions

Table 10 Yields $(\%, \mathbf{d b})$, number average molecular weights (MW) and ultimate analyses ( $\%$, daf) of DS-GPC. fractions

a) Yubari-DS

\begin{tabular}{|c|c|c|c|c|c|c|c|}
\hline \multirow{2}{*}{$\begin{array}{l}\text { Fr. } \\
\text { no. }\end{array}$} & \multirow{2}{*}{ Yield } & \multirow{2}{*}{ MW } & \multirow{2}{*}{$\mathrm{C}$} & \multirow{2}{*}{$\mathrm{H}$} & \multirow{2}{*}{$\mathrm{O}^{*}$} & \multicolumn{2}{|c|}{ Atomic ratio } \\
\hline & & & & & & $\mathrm{H} / \mathrm{C}$ & $\mathrm{O} / \mathrm{C}$ \\
\hline 1 & 18.6 & 20400 & 83.6 & 6.6 & 9.8 & 0.94 & 0.087 \\
\hline 2 & 19.3 & 16700 & 83.6 & 6.8 & 9.6 & 0.96 & 0.087 \\
\hline 3 & 14.4 & 14600 & 83.3 & 6.6 & 10.1 & 0.94 & 0.091 \\
\hline 4 & 12.9 & 12000 & 83.4 & 6.4 & 10.2 & 0.91 & 0.092 \\
\hline 5 & 15.7 & 10700 & 83.7 & 6.4 & 9.9 & 0.91 & 0.088 \\
\hline 6 & 16.5 & 2670 & 84.0 & 6.7 & 9.3 & 0.94 & 0.083 \\
\hline \multicolumn{8}{|c|}{ b) Taiheiyo-DS } \\
\hline \multirow{2}{*}{$\begin{array}{l}\text { Fr. } \\
\text { no. }\end{array}$} & \multirow{2}{*}{ Yield } & \multirow{2}{*}{ MW } & \multirow{2}{*}{$\mathrm{C}$} & \multirow{2}{*}{$\mathrm{H}$} & \multirow{2}{*}{$\mathrm{O}^{*}$} & \multicolumn{2}{|c|}{ Atomic ratio } \\
\hline & & & & & & $\mathrm{H} / \mathrm{C}$ & $\mathrm{O} / \mathrm{C}$ \\
\hline 1 & 11.2 & 32600 & 78.8 & 6.6 & 14.6 & 1.00 & 0.139 \\
\hline 2 & 10.2 & 29600 & 77.6 & 6.8 & 15.6 & 1.04 & 0.150 \\
\hline 3 & 12.0 & 25000 & 77.8 & 6.8 & 15.4 & 1.05 & 0.148 \\
\hline 4 & 10.5 & 20300 & 78.3 & 6.6 & 15.1 & 1.01 & 0.145 \\
\hline 5 & 9.0 & 1020 & 78.3 & 8.3 & 13.4 & 1.26 & 0.128 \\
\hline DS-BIS & 46.6 & - & 77.0 & 6.7 & 16.3 & 1.04 & 0.159 \\
\hline
\end{tabular}

* By difference 
Table 11 Structural parameters of DS-GPC. fractions

a) Yubari-DS

\begin{tabular}{|c|c|c|c|c|c|c|c|}
\hline $\begin{array}{l}\text { Fr. } \\
\text { no. }\end{array}$ & $\mathrm{fa}$ & $\sigma a l$ & $\begin{array}{c}\text { Struc } \\
\sigma o\end{array}$ & $\begin{array}{l}\text { paramete } \\
\mathrm{Hau} / \mathrm{Ca}\end{array}$ & $\mathrm{Ho} / \mathrm{H} \alpha$ & $\mathrm{M}(\mathrm{Us})$ & $\mathrm{n}$ \\
\hline 1 & 0.64 & 0.35 & 0.18 & 0.74 & 1.2 & 279 & 73.1 \\
\hline 2 & 0.62 & 0.37 & 0.18 & 0.76 & 1.1 & 265 & 63.0 \\
\hline 3 & 0.63 & 0.36 & 0.19 & 0.76 & 1.1 & 263 & 55.5 \\
\hline 4 & 0.64 & 0.36 & 0.21 & 0.70 & 1.2 & 337 & 35.6 \\
\hline 5 & 0.65 & 0.36 & 0.19 & 0.71 & 1.1 & 314 & 34.1 \\
\hline 6 & 0.63 & 0.37 & 0.18 & 0.72 & 1.2 & 309 & 8.6 \\
\hline \multicolumn{8}{|c|}{ b) Taiheiyo-DS } \\
\hline \multicolumn{3}{|l|}{ Fr. } & \multicolumn{4}{|c|}{ Structural parameter } & \\
\hline no. & $\mathrm{fa}$ & $\sigma \mathrm{al}$ & $\sigma \mathrm{O}$ & $\mathrm{Hau} / \mathrm{Ca}$ & $\mathrm{Ho} / \mathrm{H} \alpha$ & $\mathrm{M}(\mathrm{U} s)$ & $\mathrm{n}$ \\
\hline 1 & 0.59 & 0.37 & 0.27 & 0.87 & 1.1 & 208 & 156.7 \\
\hline 2 & 0.57 & 0.38 & 0.28 & 0.94 & 1.1 & 186 & 159.1 \\
\hline 3 & 0.57 & 0.37 & 0.28 & 0.94 & 1.2 & 184 & 135.9 \\
\hline 4 & 0.58 & 0.37 & 0.28 & 0.87 & 1.2 & 212 & 95.8 \\
\hline 5 & 0.42 & 0.40 & 0.33 & 0.92 & 2.7 & 259 & 3.9 \\
\hline
\end{tabular}

率，95\%）の分子量分布を調べて900〜48000（最多留 分の平均分子量は3300）の成分を得ており，この 48000 の成分が当ジオキサン可溶分に相当するのではないか と考えられる。高分子量の成分であるため最初MWEL 40 万のゲル（G-4000HG）を用いて分別を試みたが， ゲルの試料吸着が甚だしく使用に耐えなかった。溶出 曲線(Fig.2) の形がよくないのは適当なゲルがみあた らずMWEL3500のゲルを用いたことによるが分子量順 にはほぼ分離されている (Fig.3)。

両炭D Sを分子量の順に 5〜 6Fr. に分割し，収率， 平均分子量ならびに元素分析值を Table 10た，構造パ ラメータをTable 11と Fig. 8にとれぞれ示した。Table 10 より, 太平洋炭は夕張炭よりも $\mathrm{C} \%$ は平均で $5 \%$ 程 度低く, $\mathrm{O} \%$ は高い。また夕張炭の上限分子量 (GPC. Fr. 1)が太平洋炭の下限に近い GPC. Fr. 4の平均分子 量に相当するなど元素分析值においても分子量分布に おいても両炭種間に差異がみられる。

同様の差異は構造パラメータ(Table 11, Fig.8) に も認められ, 太平洋炭は夕張炭よりも $\mathrm{fa}$ と $\mathrm{M}\left(\mathrm{Us}_{\mathrm{s}}\right)$ が 低く， $\sigma 0$ と $\mathrm{n}$ が大きい。しかし各構造パラメータの分 布範囲はやはり狭く, 太平洋炭の Fr. 5 を除くと両炭 $\mathrm{Ho} / \mathrm{H} \alpha$ の $\mathrm{R}^{\prime}$ は 0.1 以内，その他の $\mathrm{R}^{\prime}$ は 0.07 以内に ある。Fig. 3 より, 夕張炭のFr.6と太平洋炭のFr. 5 は それぞれ他と著しく異なるが，Table 11ならびにFig. 3 から, 夕張炭 Fr. 6 は分子量が小さいだけで単位構
造のほぼ同じものからなるのに対し，太平洋炭Fr.5は 芳香族性，置換度，側鎖長さいずれも他より大きく異 質の成分と思われた。

6 種の各溶剂可溶分中に存在する種々の分子量成分
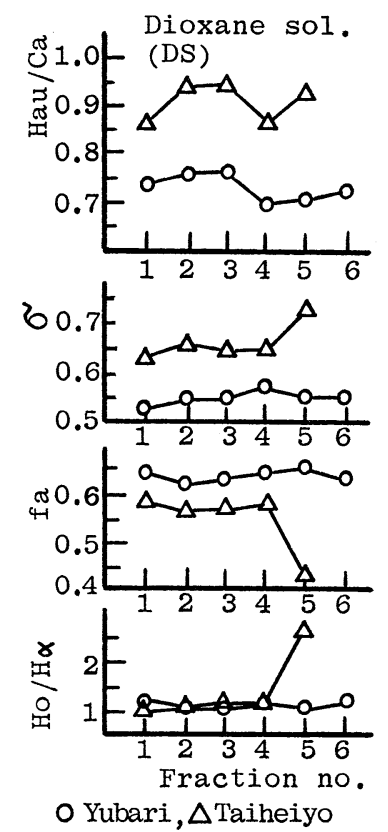

Fig. 8 Structural parameters versus fraction no. of GPC. fractions 
(GPC, Fr.) の構造パラメータが逐次抽出によってぞ のように変化するのかを分布の範囲とその平均值をも って Fig.9 亿示した。これら構造パラメータの範团は もちろん分画数によって大きく変化するが，できるだ け条件を同じくしたため両炭の拈特よその傾向は読み とりうるものと考觉られる（平均値が上下範囲の中心 にない場合には，その中に特異な值を有する Fr.が 1 〜 $2 \mathrm{Fr}$. 存在することを意味する)。詳細に観察した場 合種々両炭の差異を指摘できるが，概して太平洋炭で は平均分子量に大差があるにもかかわらず1)，HS〜 D S KかけてはM(Us)が，またC S〜D S ではHau/

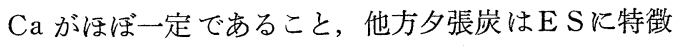
があり，その各構造パラメータ平均值はH S D D K おいて最大值ないし最小值を示すことが多くかつ $\mathrm{M}$ (Us) の分布範囲は狭いにもかかわらず $\mathrm{Ho} / \mathrm{H} \alpha$ の分 布範囲は比較的広いことなどがあげられる。

各側鎖炭素数について, 単位構造と fa との関係を Fig.10に示した。両炭HSならびにE S は比較的広範 囲分布し, 太平洋炭 CS, AS, EAS, DSの多くが 1 〜 環の芳香環に側鎖炭素が $4 \sim 8$ 個付いたものから なるのに反し, 夕張炭は全体に太平洋炭よりも下方に 位置し， $2 \sim 3$ 環の芳香環に側鎖炭素が $5 \sim 9$ 個付い たものからなっている。な执太平洋炭H S の各 GPC. Fr.はfa $0.70, \mathrm{CS}(\mathrm{Us}) 3$ からfa $0.26, \mathrm{CS}$ (Us) 10 ま で規則的に配列しているが，夕張炭H S にはこの傾向 が認められないことる炭種間における差異のひとつに あげうる。

次に両炭各 GPC.Fr. の重合度 nについて, 構造単 位質量 $\mathrm{M}\left(\mathrm{Us}_{\mathrm{s}}\right)$ と平均分子量との関係を Fig.11に示し た。DS-GPC.Fr.を除くその他のGPC.Fr.は, 夕張 炭ではM(Us) $120 \sim 330, \mathrm{n} \leqq 16$, 太平洋炭では $\mathrm{M}\left(\mathrm{US}_{\mathrm{s}}\right)$ $120 \sim 210, \mathrm{n} \leqq 35$ と, 炭種間では後者の方が単位質量 範囲が幾分狭く，逆酒重合度は高かった。な招これら にはベンゼン不溶化成分すなわち太平洋炭D S の約50 \%ならびにベンゼン可溶分の約 $13 \%$ を占める 夕張炭 DIS の結果が記載されていないことからここれらを 含めるとベンゼン可溶分の重合度範囲はさらに広がる ものと考光られる。

$$
\text { 4. 総 括 }
$$

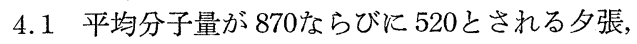
太平洋両炭ベンゼン可溶分中に，それぞれ MW 12000 と $10^{5}$ 程度の非常に高分子量の成分が存在した。

4.2 両炭シクロヘキサン可溶分の分子量範围 (440 〜4910）はn一へキサン可溶分の分子量範囲より広かっ たが, 各構造パラメータの分布範囲は狭く, ことに夕
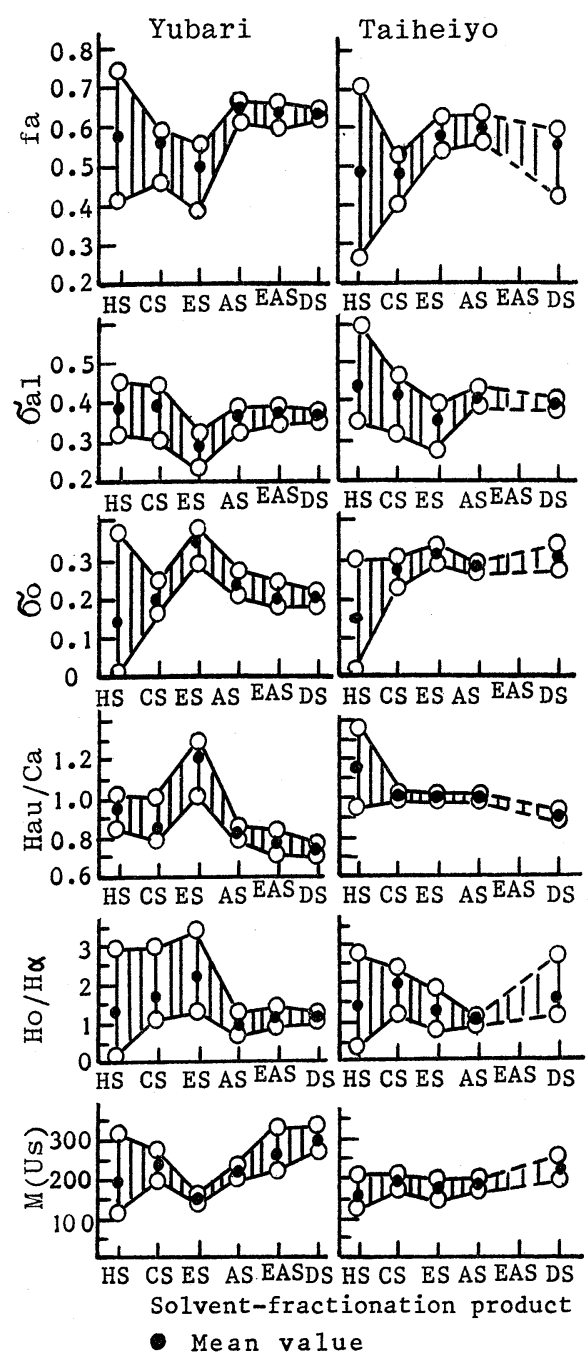

Fig. 9 Parameter ranges of the solventfractionation products

張炭GPC.Fr. 2〜6（約61\%）は，Ho/H $\alpha$ を除いて平 均值 \pm 0.03 範囲にあった。

4.3 夕張炭エタノール可溶分は, 6 種の溶剤可溶分 中 $\mathrm{fa}, \sigma \mathrm{al}, \mathrm{M}(\mathrm{Us})$ が最も低く, かつ $\sigma 0$ の大きな成分 よりなっていた。概してこれらの各構造パラメータ平 均値は最大值ないし最小值をとることが多く, $\mathrm{M}\left(\mathrm{Us}_{\mathrm{s}}\right)$ の分布範囲は狭かったが, $\mathrm{Ho} / \mathrm{H} \alpha$ の分布範囲は割に 広かった。

4.4 太平洋炭アセトン可溶分（MW，5600～1400） は夕張炭アセトン可溶分（MW, 3100 580）に比べて 低分子量成分が非常に少なく, 炭素含量にも夕張炭 $80.8 \pm 1.3 \%$, 太平洋炭 $77.3 \pm 0.6 \%$ ような差異が炭 

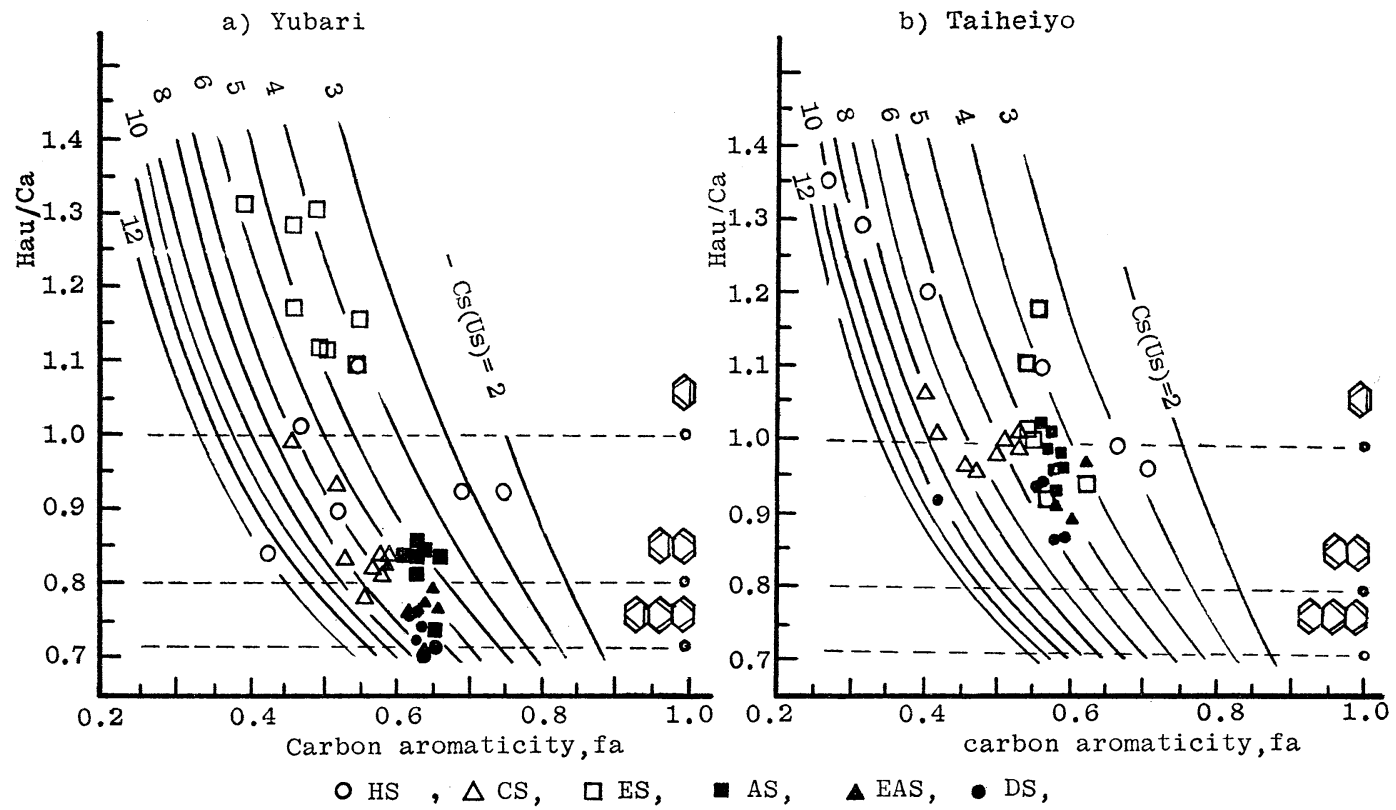

Fig. 10 Relation between unit structures and no. of aliphatic carbons attached to them of GPC. fractions of each solvent-fractionation product

a) Yubari

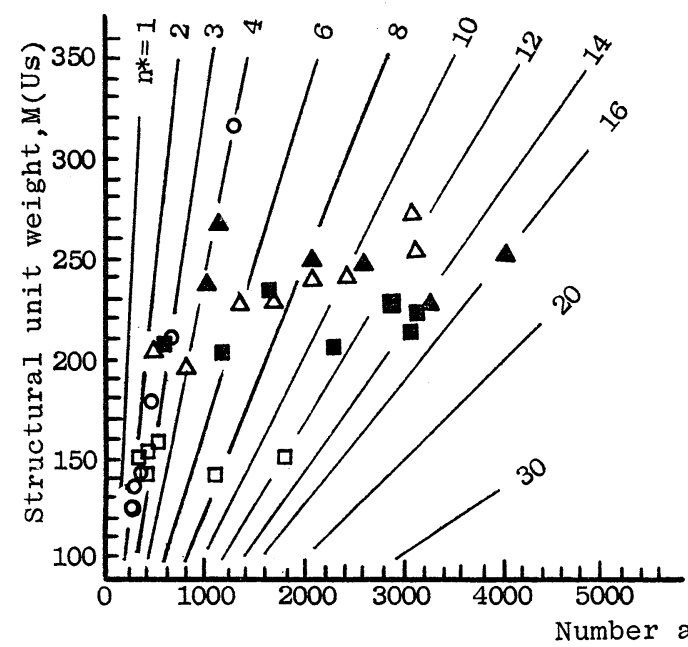

b) Taiheiyo

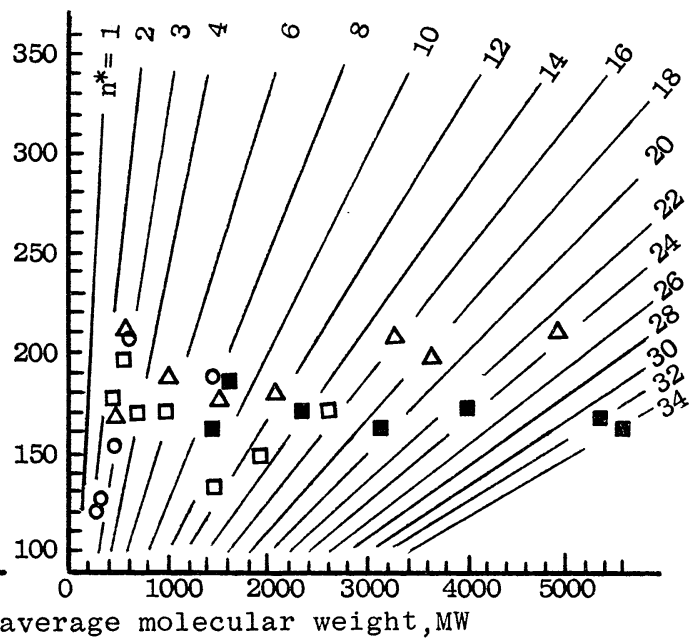

OHS, $\triangle \mathrm{CS}, \quad \square \mathrm{ES}, \quad \mathrm{AS}, \quad \mathrm{EAS}, \quad * \mathrm{n}=\mathrm{MW} / \mathrm{M}(\mathrm{US})$

Fig. 11 Structural unit weights and their polymerization degrees of GPC. fractions

種間にみられた。

4.5 太平洋炭の 各溶剤可溶分は概して 平均分子量 にかなり差があるにもかかわらず, HS, CS, ES, AS, EAS, DSのM(Us)が，またCS, ES, AS, EAS, DS では $\mathrm{Hau} / \mathrm{Ca}$ がほぼ一定であった。
4. 6 太平洋炭 CS, AS, EAS, DS の多くが $1 \sim 2$ 環の芳香環に側鎖炭素が 4 〜 個付いたものからなる のに対し, 夕張炭では $2 \sim 3$ 環の芳香環に側鎖炭素が $5 〜 9$ 個付いたものからなっていた。

本研究の一部は文部省科学研究費補助金（エネルギ 
一特別研究）を得て実施したものである。研究にあた り, 本学部学生の坂井幸生君ならびに富山医科薬科大 学, 有機微量元素分析室の小川誠技官の協力を得た。 記して感謝の意を表する。

\section{文献}

1）加藤 勉, 橋本茂樹, 塚島 寛, 燃協誌, 60,426 (1981)

2) 加藤 勉, 孕石貴幸, 和田清人, 山下 剛, 塚島 寛，ibid., 60, 968 (1981)

3) Wawzonek, S. and Wearring, D., J. Amer. Chem. Soc., 81, 2067 (1959)

4) Paul, N.E., Lipkin, D. and Weissman, S. I., ibid., 78, 116 (1956)

5) Velthorst, N.H. and Hoijtink, G.J., ibid., 87, 4529 (1965)

6) Sternberg, H.W. and Delle Donne, C. L., Amer. Chem. Soc., Div. Fuel chemistry reprints, Vol.12, No.4, 13 (1968)

7) Sternberg, H.W., Delle Donne, C.L., Pantages, P., Moroni, E.C. and Markby, R.E., Fuel, 50, 432 (1971)

8) Sternberg, H.W. and Delle Donne, C. L., ibid., 53, 172 (1974)

9) Niemann, K. and Hombach, H.P., ibid., 58, 853 (1979)

Niemann, K. and Richter, U.B., ibid., 61, 423 (1982)

10) Alemany, L. B. and Stock, L. M., ibid., 61, 250 (1982)

11) Ignasiak, B.S. and Gawlak, M., ibid., 56, 216 (1977)

12) Dogru, R., Erbatur, G., Gaines, A.F., Yurum, Y., Icli, S. and Wirthlin, T., ibid., 57, 399 (1978)

13) Wachowska, H., ibid., 58, 99 (1979)

14) Ouchi, K., Hirano, Y., Makabe, M. and Itoh, H., ibid., 59, 751 (1980)
15) Lazarov, L., Rashkov, I. and Angelov, ibid., 57, 637 (1978)

Lazarov, L., Stefanova, M. and Petrov, K., ibid., 61, 58 (1982)

16) Miyake, M., Sukigara, M., Nomura, M. and Kikkawa, S., ibid., 59, 637 (1980)

17) Tsukashima, H. and Kato, T., Research on effective use of energy, Vol.2, 447 (1982)

18) Franz, J.A. and Skiens, W.E., Fuel., 57, 502 (1978)

19) Larsen, J. W. and Urban, L. O., J. Org. Chem., 44, 3219 (1979)

20) Speight, J. G. and Moschopedis, S.E., Fuel, 59, 440 (1980)

21) Collins, C. J., Hombach, H. P., Maxwell, B., Woody, M.C. and Benjamin, B. M., J. Amer. Chem. Soc., 102, 851 (1980) Collins, C. J., Hombach, H.P., Maxwell, B. E. and Benjamin, B. M., Erdoel und Kohle-Erdgas-Petrochemie, 35, 386 (1982)

22) Eargle, Jr., D. H., J. Org. Chem., 28, 1703 (1963)

23) Itoh, M., Yoshida, S., Ando, T. and Miyaura, N., Annual report of coal research institute, No.1, 32 (1975)

24) Ignasiak, T., Kemp-Jones, A. V. and Strausz, O.P., J. Org. Chem., 42, 312 (1977)

25) Kuhlmann, E., Boerwinkle, E. and Orchin, M., Fuel, 60, 1002 (1981)

26) Alemany, L. B., King, S. R. and Stock, L. M., ibid., 57, 738 (1978)

Alemany, L. B. and Stock, L. M., ibid., 61, 1088 (1982)

27) Wachowska, H. and Pawlak, W., ibid., 56, 422 (1977)

Wachowska, H. M., Nandi, B. N. and Montgomery, D.S., ibid., 58, 257 (1979) 


\title{
Structural Analysis of the Methylated Product of Coal (III)
}

-GPC. Separation of Solvent-fractionation Products

from Reductive Methylation Products-

Tsutomu Kato, Hiroyuki MiYaKe, Fumihiro KoUnUSHI and Hiroshi Tsukashima

\author{
(Faculty of Engineering, Toyama University)
}

SYNOPSIS : - In cases of carring out investigation on the solubilization mechanism of coals, and of also making highly utilization of soluble products of coals as fuel and chemicals, it is desirable for us to obtain more detailed information about soluble product from coal.

Structural parameters and others of six solvent-fractionation products which were fractionated by GPC, were examined and compared.

Asphaltenes prepared from methylated Yubari and Taiheiyo coals contained components of number average molecular weight having 20400 and 32600 , respectively.

As to Taiheiyo coal, solvent-fractionation products differed markedly with regard to their molecular weights (MW. range, 390 47600), but HS (n-hexane sol.), CS (Cyclohexane sol.), ES (Ethanol sol.), AS (Acetone sol.), EAS (Ethyl acetate sol.), and DS (Dioxane sol.) nevertheless resembled closely one another in structural unit weight, $M(\mathrm{Us})$, and $\mathrm{CS}$, ES, AS, EAS, and DS in the degree of condensation in aromatic ring, $\mathrm{Hau} / \mathrm{Ca}$.

In general CS, AS, EAS, and DS of Taiheiyo coal consisted of $1 \sim 2$ aromatic ring with $4 \sim 8$ aliphatic side chain carbons, whereas those of Yubari coal, $2 \sim 3$ aromatic rings with $5 \sim 9$ aliphatic side chain carbons.

Moreover structural characteristics of each solvent-fractionation product were discussed.

\section{Key Words}

Reductive methylation, Solvent-fractionation,

Gel permeation chromatography, Structural analysis 